will be used, not only by parties from secondary schools but also by other parties from England. Details of the courses at the Centre and other courses arranged by the Scottish Field Studies Association can be obtained from 141 Bath Street, Glasgow, C.2.

\section{The Acoustical Society of America}

Prof. Cyril M. Harris, of Columbia University, has been elected president of the Acoustical Society of America. As such, he succeeds Dr. C. Paul Boner, of the University of Texas. The following elections have also been made: Dr. Robert W. Morse, professor of physics at Brown University, president-elect; Dr. Vincent Salmon, Stanford Research Institute in Menlo Park, California. vice-president; Wallace Waterfall, of New York City, re-elected secretary; Herbert A. Erf, of Cleveland, Ohio, re-elected treasurer; and two Council members, Dr. Thomas D. Northwood, of the National Research Council of Canada, and Dr. Ernest Yeager, of Western Reserve University in Cleveland, Ohio.

\section{American Academy of Arts and Sciences: Foreign Honorary Members}

The American Academy of Arts and Sciences at its one hundred and eighty-fourth annuel meeting on May 13, in Boston, elected 115 new Fellows from the United States, and 17 new Foreign Honorary Members, including : Israel M. Gelfand, Moscow State University; L. van Hove, CERN, Geneva; Manfred Eigen, Max-PlanckInstitut für Physikalische Chemie, Goettingen; Frod Hoyle, University of Cambridge; P. V. Danckwerts, University of Cambridge; Aharon Katchalsky, Weizmann Institute of Science, Rehovoth; J. C. Kendrew, University of Cambridge; François Jacob, Pasteur Institute, Paris; Sir Howard Florey, University of Oxford; M. Fortes, University of Cambridge; J. V. M. Robinson, University of Cambridge.

\section{University News :}

Aberdeen

THE following appointments to lectureships have been announced: Dr. J. R. Sargent and Dr. Alison M. Pumphrey (biological chemistry); Dr. R. J. Ellis (botany); R. H. McGuigan (engineering); Dr. D. M. Guthrie (natural history); Dr. W. W. Bell, Dr. W. J. L. Buyers and A. M. Flett (natural philosophy); Dr. W. P. Brown (psychology); C. P. Burnham (soil science).

Bangor

Dr. J. SherIDAN, at present reader in chemistry in the University of Birmingham, has been appointed to the newly instituted chair of physical and inorganic chemistry in the University College of North Wales at Bangor. The following appointments have been announced: Senior lecturer, Dr. A. D. Bradshaw (agricultural botany); Mr. E. R. Huggard (forestry); Dr. J. M. Thomas (chemistry); Dr. R. H. Tredgold (physics). Lecturer, Mr. H. G. Flegg, Mr. J. Y. Kassab and Miss I. R. P. Finlayson (pure mathematics); Dr. J. E. Bailey and Dr. P. R. Thornton (engineering science); Dr. J. Popplewell (physics).

\section{Nottingham}

Dr. W. B. Hegrnbotham, at present senior lecturer and head of the Department of Production Engineering, has been appointed Cripps professor of production engineering. The title of reader has been conferred on the following: Dr. C. W. J. Granger (econometries), Dr. E. E. Jones (mathematics), Dr. W. F. Nash (physics), Dr. J. .C. Roberts (chemistry), Dr. A. J. Rowell (geology).

\section{Newcastle upon Tyne}

DR. J. R. RINGRose, senior lecturer in mathematics, has been appointed to the second chair of pure mathematics as from August 1. The following appointments to lectureships have also been made: Dr. B. Clark (pharmacology); C. B. Ferry (pharmacology); Dr. D. M. Conning (pathology); R. A. Billett (mechanical and marine engineering); Dr. R. S. Hill (mechanical and marine engineering).

\section{Announcements}

Dr. J. M. Ziman, of King's College, lecturer in physics in the Cavendish Laboratory and professor-elect of theoretical physics, University of Bristol, has been awarded the Hopkins Prize of the Cambridge Philosophical Society. Dr. Ziman is well known for his work in theoretical solid-state physics, and the award is for his contributions to the electron properties of liquid metals. The Prize has been awarded every three years since 1867 for work in mathematical-physical or related fields by a member of the University of Cambridge. The first four prize winners were Stokes, Maxwell, Rayleigh and Kelvin. The present award relates to the period 1960-63 and is of the value of $£ 200$.

MIss JoAN Bostock has been appointed general secretary of the Association of Agriculture in succession to Mr. Alexander Hay. Previously Miss Bostock was deputy secretary.

A menting of the Bone and Tooth Society will be held in the Dunn Nutritional Laboratory, Cambridge, on June 4. Further information can be obtained from B. Cohen, Royal College of Surgeons, Lincoln's Inn Fields, London, W.C.2.

AN international biophysies meeting, arranged by the International Organization for Pure and Applied Biophysics, will be held in Paris during June 22-27. Further information can be obtained from Prof. J. Tonnelat, Laboratoire de Biologie Physico-Chemique, Orsay, Seine et Oise.

A CONHERENCE on "Precision Electromagnetic Measurements" will be held at the National Bureau of Standards, Boulder, Colorado, during June 23-25. The conference will include sessions on : frequency and time standards and techniques; quantum electronics; d.c. and audio-frequency measurements; radio frequency and microwave measurements; measurements on materials. Further information can be obtained from Professional Associates, 6520 Clay Road, St. Louis, 17, Missouri.

The third congress of the International Federation of Societies of Cosmetic Chemists, organized by the Society of Cosmetic Chemists, will be held in New York during June 21-28. The programme will include sessions on: safety aspects of cosmetic usage; role of instrumentation in cosmetic research and control; cosmetics versus skin ageing; cosmetics and micro-organisms. Further information can be obtained from the General Secretary, Society of Cosmetic Chemists of Great Britain, 2 Lovers Walk, London, N.3.

THE fourteenth annual conference of the Institute of Rural Life at Home and Overseas on "International Co-operation in Development Programmes" will be held at the Department of Technical Co-operation, London, during June 8-9. The programme will include sessions on: food and agriculture; housing and health; the individual and the community; education and employment. Further information can be obtained from the Secretary, Institute of Rural Life at Home and Overseas, 59 Bryanston Street, London, W.1.

Erratum. In the article entitled "Estimation of Ruby Laser Oscillation Loss" by Joseph I. Masters, which appeared on p. 442 of the A.ugust 3, 1963, issue of Nature, equation 1 should read :

$$
P_{\text {rel }}=\{A-\ln r\} /\{[2 A /(1+\exp (-42 / T))]+\ln r\}
$$

